Article

\title{
Erosion-Corrosion of AISI 304L Stainless Steel Affected by Industrial Copper Tailings
}

\author{
Álvaro Soliz ${ }^{1, * \mathbb{C}}$, Luis Cáceres ${ }^{2}$ (), Fabiola Pineda ${ }^{3}$ and Felipe Galleguillos ${ }^{2}$ \\ 1 Departamento de Ingeniería en Metalurgia, Universidad de Atacama, Copiapó 1530000, Chile \\ 2 Departamento de Ingeniería Química y Procesos de Minerales, Universidad de Antofagasta, \\ Antofagasta 1240000, Chile; luis.caceres@uantof.cl (L.C.); felipe.galleguillos.madrid@ua.cl (F.G.) \\ 3 Departamento de Ingeniería de Mecánica y Metalúrgica, Escuela de Ingeniería, Pontificia Universidad \\ Católica de Chile, Santiago 8331150, Chile; fabiola.pineda@gmail.com \\ * Correspondence: alvaro.soliz@uda.cl; Tel.: +56-52-225-5614
}

Received: 30 June 2020; Accepted: 24 July 2020; Published: 27 July 2020

check for updates

\begin{abstract}
A comprehensive analysis of the erosion-corrosion behavior of AISI 304L stainless steel immersed in $0.5 \mathrm{M} \mathrm{NaCl}$ solution with the addition of industrial tailing particles obtained from the copper mining industry is reported. From fundamental studies using combined measurements of potentiodynamic and weight loss techniques, the pure corrosion, pure erosion, and their synergism on the total wear rate were evaluated. The results showed that the presence of soluble chemical reagents dragged by tailing particles significantly affects the pure corrosion rate in comparison with a $\mathrm{NaCl}$ solution without these chemical reagents. In addition, the wear of stainless steel by pure erosion was found to be more important than that of pure corrosion. Erosion-corrosion tests performed under an open circuit potential behavior indicate lower and higher wear values than that obtained for erosion and corrosion rates, respectively. Through these results, it was possible to determine an antagonistic effect for AISI 304L stainless steel in industrial tailings slurries. These results are supported by changes in the electrochemical parameters, passive film stability, and morphological attributes.
\end{abstract}

Keywords: antagonism; AISI 304L stainless steel; erosion-corrosion; mining tailing

\section{Introduction}

The austenitic stainless steel is the most widely used alloy in multiple industrial applications such as architecture, mining, chemistry, metallurgy, and marine equipment and infrastructure. Along with the magnitude of alloy exposure to environmental conditions, there are many cases where aggressive media are multiphase in nature as they consist of water, air, and solid particles of different sizes. In particular, in the mining industry, due to their high resistance to corrosion, moderate cost, and mechanical performance, stainless steel has been extensively used. Indeed, the austenitic stainless steel type $304 \mathrm{~L}$ is employed in pipes, pumps, containers, or other components such as nuts or bolts. The presence of chromium and nickel in these steels improves considerably its corrosion resistance, as a result of the spontaneously formed passive film on its surface [1-3]. However, this passive film can be strongly destabilized originating its failure or breakdown that initiates a localized corrosion process such as pitting corrosion [4-7]. In the presence of slurries, pitting corrosion can be increased as a result of synergistic interaction with solid particles that impinge upon the metal surface. The corrosion rate and passive film breakdown have been extensively studied in austenitic stainless steel [5,8-12], covering situations when this material is also subjected to mechanical damage from solid particles [13-19], which is described as an erosion-corrosion phenomenon [20].

In a copper production chain, specifically in the beneficiation of plants, the most significant water consumption takes place in the flotation, transportation of concentrates, and tailing disposal stages. 
In this context, tailings are a common by-product of the copper minerals concentration stage, which is later pumped as a high-density slurry from thickener tanks or tailing dams into its final disposal site. Note that the presence of albite, pyrite, quartz, magnetite, and others minerals are identified in these steps. Most studies on erosion-corrosion behavior for AISI 304L have been conducted using synthetic slurries prepared from quartz and/or alumina particles, in which the electrochemical corrosion is enhanced by the mechanical damage [21-26]. Only a few works have studied the erosion-corrosion of AISI 304L stainless steel in the presence of industrial tailings [27]. On the other hand, the interpretation of the surface behavior in the presence of industrial slurries can be challenging, principally because industrial tailings are specific to each industrial or mining site. In this regard, during the mineral processing circuit, chemical reagent selection and dosing such as collectors, depressants, frothers, and $\mathrm{pH}$ modifiers are adopted in terms of a local mineralogy that frequently is highly variable. These reagents can modify the solution chemistry and additionally promote complex solid-liquid interactions associated with a mass transfer.

The wear of metallic samples that are in contact with slurries can be described in terms of weight loss, as an additive contribution of individual corrosion and erosion degradation mechanisms, including the synergism between these two mechanisms according to Equation (1) [28]:

$$
T_{w l}=C_{0}+W_{0}+S_{E-C}
$$

where $T_{w l}$ is the total weight loss caused by erosion-corrosion, $C_{0}$ is the weight loss due to a pure electrochemical corrosion mechanism, $W_{0}$ is the weight loss due to a pure erosion mechanism, and $S_{E-C}$ is the weight loss due to the synergism effect. The synergistic effect can be a positive or negative value, depending on the $C_{0}, W_{0}$, and $T_{w l}$ values.

The severity of the damage caused by chemical, electrochemical, and/or mechanical effects is of great relevance for multiple industrial sectors, where their impact is not only reflected in technical aspects but also in financial aspects. Typically, corrosion and/or erosion phenomena are the most common degradation mechanisms present in mining industries, where the demand for information is mainly focused on studies under industrial conditions and widely used alloys, including AISI 304L stainless steel. Consequently, in this work, we evaluate the wear behavior of stainless steel AISI 304L using potentiodynamic and weight loss techniques. In particular, the approach of this study is to determine the synergism effect between corrosion and erosion processes on the stainless steel in the presence and absence of industrial tailing particles. The use of industrial tailing samples from the copper mining industry will fill the existing gap of information for these conditions. Additionally, the variations in the electrochemical behavior in terms of corrosion, erosion, passivation, synergism, and morphological aspects are discussed.

\section{Materials and Methods}

\subsection{Materials}

The samples used in this work were made from commercial stainless steel bars type AISI 304L with a nominal composition of (wt.\%): Cr 17.410, Ni 8.210, Mn 1.250, S 0.003, P 0.035, Si 0.530, C 0.030, and Fe balance. The bars were cut and machined up to obtain cylindrical specimens with dimensions of external diameter $9.5 \mathrm{~mm}$, inside diameter $6.5 \mathrm{~mm}$, and height $10 \mathrm{~mm}$, which were used as a rotating cylinder electrode for both potentiodynamic and weight loss measurements. Prior to the experiments, the samples were mechanically abraded up to 1200 grit SiC paper, degreased with isopropyl alcohol in an ultrasonic bath, cleaned with deionized water, and finally dried in a flow of hot air. After that, the samples were weighted at least three times and immediately transferred to the experimental cell.

The test solution was $0.5 \mathrm{M} \mathrm{NaCl}$ prepared from an analytical grade reagent (Merck S.A., Santiago, Chile) and deionized water. The slurry was prepared using the test solution with an erodent concentration of $50 \mathrm{wt}$ \% from an industrial tailings sample obtained from a local Chilean mining copper plant (Copiapó, Chile). Due to the complex combination of chemical components that come 
from both the ore and the industrial additives, a second test solution which comes from the slurry filtration, and that supposedly contains soluble components added as additives in the froth flotation stage, was used as reference. Prior to continuing the measurements, the test solutions, i.e., the filtrate solutions, and the tailings slurry were bubbled with atmospheric air for $10 \mathrm{~min}$ to maintain a constant dissolved oxygen (DO) concentration equivalent to $6.7,6.4$, and $6.4 \mathrm{mg} / \mathrm{L}$, respectively. On the other hand, the $\mathrm{pH}$ of both the test solution and filtrate solution was 6.56 , and the $\mathrm{pH}$ of the slurry was 8.05 . All experiments were performed at room temperature of $22 \pm 1^{\circ} \mathrm{C}$.

\subsection{Experimental Measurements}

In order to study the wear rates caused by corrosion, erosion, and the erosion-corrosion degradation mechanisms, the experiments were performed at least three times using a batch-cell with a rotating cylinder accessory as shown in Figure 1. The reproducibility and repeatability were good, and there were no significant differences between the triplicate results. All electrochemical measurements including open circuit potential (OCP), linear sweep voltammetry, and chronoamperometry, were performed using a conventional three-electrode cell, with an AISI 304L stainless steel working electrode, an $\mathrm{Ag} / \mathrm{AgCl}$ ( $\mathrm{KCl}$ sat.) electrode as the reference electrode, and a spiral platinum wire as the counter electrode. This cell was connected to a potentiostat/galvanostat BioLogic VSP-300 (Biologic, Seyssinet-Pariset, France). All potentials referred to the standard hydrogen electrode (SHE).

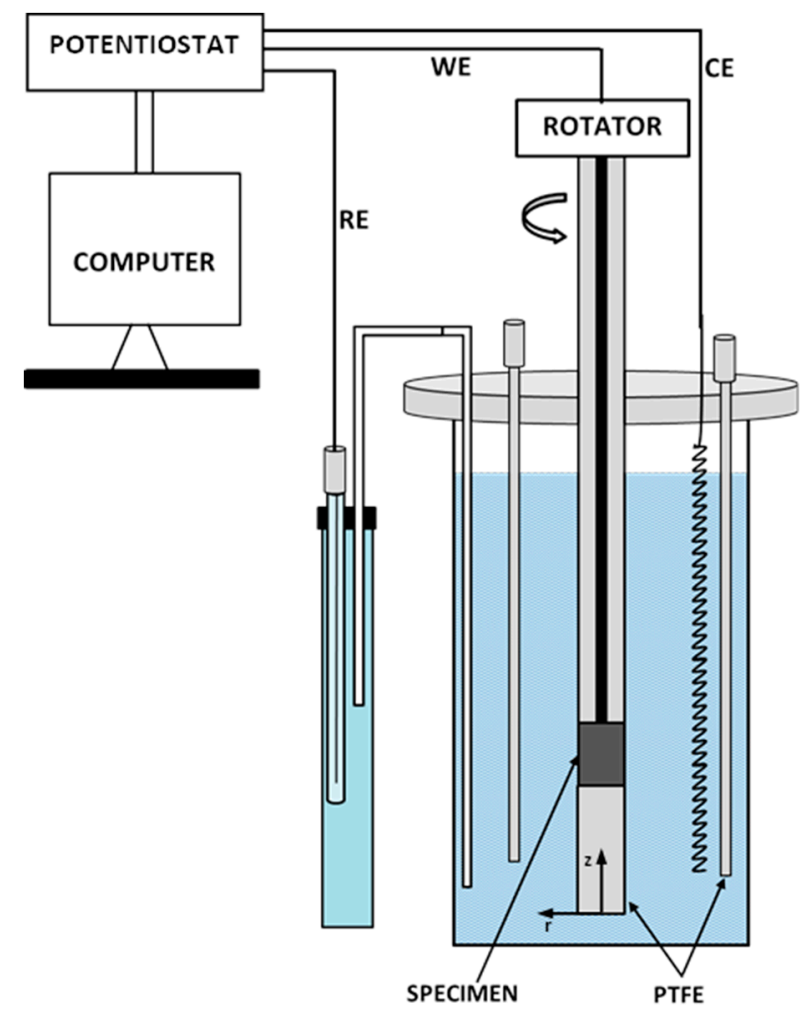

Figure 1. Scheme of the electrochemical cell configuration with a rotating cylinder electrode as the working electrode (WE), Pt as the counter electrode (CE), SHE as the reference electrode (RE), and two bar PTFE Teflon flow attenuators.

To evaluate the influence of tailing slurries on the wear of AISI 304L steel, experimental runs categorized as pure corrosion, pure erosion, and erosion-corrosion were performed at rotating velocities of 6000,7000 , and $8000 \mathrm{rpm}$ and equivalents to lineal maximum velocities of $3,3.5$, and $4 \mathrm{~m} / \mathrm{s}$, respectively.

The pure corrosion tests were performed in the absence of erodent particles considering $0.5 \mathrm{M}$ $\mathrm{NaCl}$ and filtrate solutions. For the pure corrosion analysis, polarization curves were obtained by linear 
sweep voltammetry in anodic direction at a scan rate of $1 \mathrm{mV} / \mathrm{s}$. The corrosion and electrochemical parameters were determined from a non-linear fitting of experimental polarization curves considering a charge transfer mechanism control for the anodic and cathodic active regions according to the mixed potential theory and the superposition model and following generalized Equations (2) and (3) [29]:

$$
\begin{gathered}
i=\sum_{i_{\mathrm{j}, \mathrm{cat}}}+\sum_{i_{\mathrm{j}, \text { anod }}} \\
i_{j}=i_{0, \mathrm{j}} \exp \left(2.303\left(E-E_{\mathrm{eq}, \mathrm{j}}\right) / b_{\mathrm{j}}\right)
\end{gathered}
$$

where, $i$ is the total current density, $i_{0, j}, b_{\mathrm{j}}$, and $E_{\mathrm{eq}, \mathrm{j}}$ are the exchange current density, Tafel slope, and equilibrium potential with subscripts $j$ for the respective anodic and cathodic reactions (to be discussed in the next sections).

The corrosion current density $\left(i_{\text {corr }}\right)$ and corrosion potential $\left(E_{\text {corr }}\right)$ were determined under a null total current density, and the pitting potential $\left(E_{\text {pit }}\right)$ was determined at the point where the anodic current density abruptly increases.

The pure erosion tests were performed using the chronoamperometry technique, applying a constant cathodic potential of $-300 \mathrm{mV} / \mathrm{SHE}$ on the AISI 304L electrode and in the presence of erodent particles. Prior to the tests, the samples were treated as described previously in Section 2.1, and then transferred to the cell containing the tailing slurry. The tests were run for a total time of $44 \mathrm{~h}$. The erosion-corrosion tests were performed in the presence of erodent particles and under an OCP condition on the AISI 304L electrode. The OCP was continuously monitored during a total time of $44 \mathrm{~h}$. Similar to the previous procedure, the samples were previously treated, weighed, and transferred to the cell containing the tailing slurry.

After the corrosion, erosion, and erosion-corrosion tests, the samples were washed in a citric acid solution at $2 \%$ in an ultrasonic bath to remove corrosion products and/or erodent particles, cleaned with isopropyl alcohol and deionized water, and dried in hot airflow. To calculate the weight loss attributed to pure corrosion, the corrosion current density was converted to weight loss by the application of Faraday's law [30]. The weight losses caused by pure erosion and by erosion-corrosion were determined by weighing the samples before and after the test.

Finally, the synergism $\left(S_{E-C}\right)$ was determined using Equation (1).

\subsection{Characterization and Surface Analysis}

The composition, morphology, and structure of the AISI 304L stainless steel and the erodent particles were characterized by X-ray diffraction (XRD) using a SHIMADZU XRD-6100 (Shimadzu Corp., Kyoto, Japan) with $\mathrm{Cu}-\mathrm{K} \alpha$ radiation diffractometer, and by scanning electron microscopy (SEM) using a Zeiss EVO MA 10 (Zeiss, Oberkochen, Germany) scanning electron microscope, equipped with an energy-dispersive X-ray (EDX) analyzer. Phase composition was identified using ICCDD PDF-2 International database (release 2013). Additionally, the size distribution of erodent particles was measured by laser scattering using a Malvern Mastersize 2000 (Malvern Panalytical, Westborough, MA, USA). The microstructure of AISI 304L specimens was analyzed using an Olympus BX 41M optical microscope (OM) (Olympus Corp., Shinjuku-ku, Tokyo, Japan). For this purpose, the specimens were ground up to 2000 grit $\mathrm{SiC}$ paper, polished with $0.05 \mu \mathrm{m}$ alumina slurries, and etched using a solution of $1 \mathrm{~mL} \mathrm{HNO}_{3}+2 \mathrm{~mL} \mathrm{HCl}+3 \mathrm{~mL} \mathrm{H}_{2} \mathrm{O}$ [31] for $40 \mathrm{~s}$ at room temperature. The top and cross sections of the AISI 304L specimen were inspected by SEM. For the top section, the samples were examined without further surface manipulation. For the cross section, the samples were mounted in a conductive polymer resin prepared with a hot mounting Mecapress Presi 3 (Presi, Grenoble, France), and then these specimens were abraded up to 2500 grit $\mathrm{SiC}$ paper for a proper analysis. 


\section{Results and Discussion}

\subsection{Characterization of AISI $304 \mathrm{~L}$}

Figure 2 shows an OM picture and XRD graph for AISI 304L stainless steel after sample etching preparation. The presence of an austenitic phase $(\gamma$-Fe) with small contents of ferritic phase $(\delta$-Fe) (Figure 2a) and grain sizes that varied between 5-14 $\mu \mathrm{m}$ with a mean size of $7 \mu \mathrm{m}$, which were distributed as polygonal equiaxed grains were identified. XRD analysis (Figure 2b) confirmed the presence of an austenite phase in terms of $\gamma$-Fe (111), $\gamma$-Fe (200), $\gamma$-Fe (220), $\gamma$-Fe (311), and $\gamma$-Fe (222) peaks, and a small ferrite phase $\delta$-Fe (110) peak.
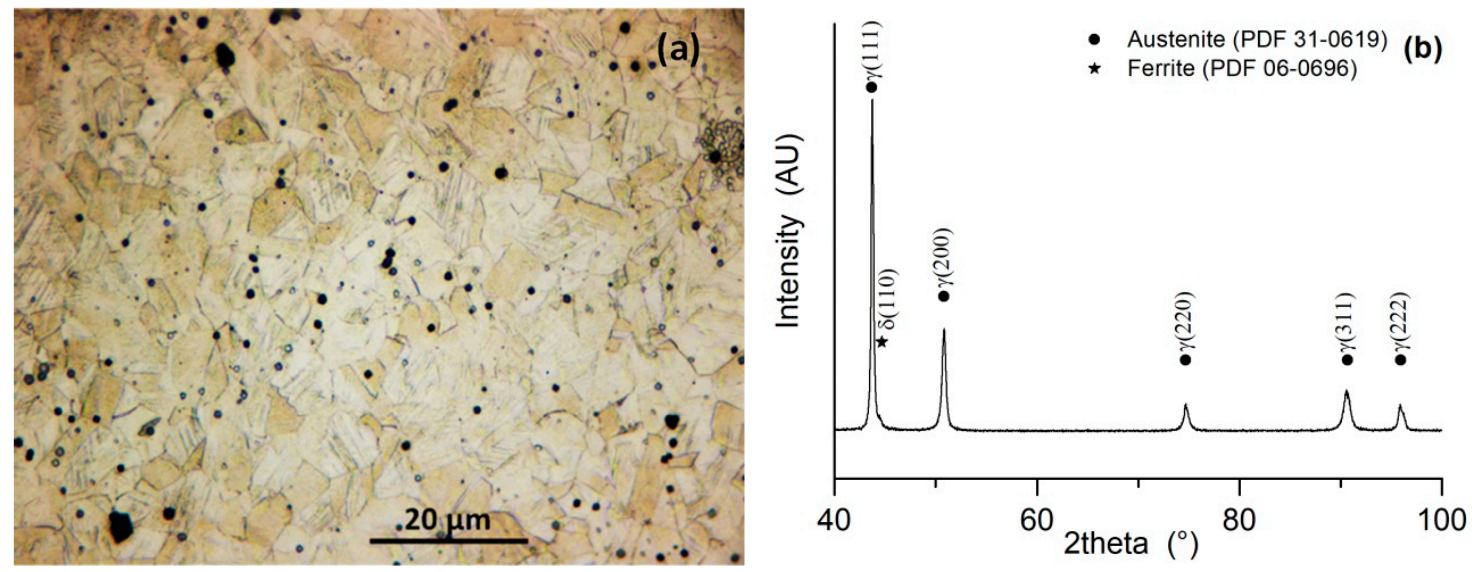

Figure 2. Microstructure (a) and XRD patterns (b) of AISI 304L stainless steel, previous to wear tests.

\subsection{Characterization of Tailing Particles}

Micrographs and elemental analysis on tailing particles obtained by SEM coupled with EDX are shown in Figure 3. This information revealed that tailings were composed of iron, silicon, aluminum, and calcium as the main elements in addition to magnesium, sulfur, sodium, potassium, copper, and titanium to a minor extent. The mineralogical composition as an XRD pattern is shown in Figure 4 as a complement of the EDX results, indicating the presence of quartz $\left(\mathrm{SiO}_{2}\right)$, alumina $\left(\mathrm{Al}_{2} \mathrm{O}_{3}\right)$, albite $\left(\mathrm{NaAlSi}_{3} \mathrm{O}_{8}\right)$, orthoclase $\left(\mathrm{KAlSi}_{3} \mathrm{O}_{8}\right)$, magnetite $\left(\mathrm{Fe}_{3} \mathrm{O}_{4}\right)$, pyrite $\left(\mathrm{FeS}_{2}\right)$, and calcium carbonate $\left(\mathrm{CaCO}_{3}\right)$ as relevant crystal phases. Furthermore, the particle distribution, presented in Figure 5, revealed a large proportion of particles having an angular shape with $\mathrm{d}_{10}, \mathrm{~d}_{50}$, and $\mathrm{d}_{90}$ values of $3.11,23.81$, and $73.35 \mu \mathrm{m}$, respectively. 

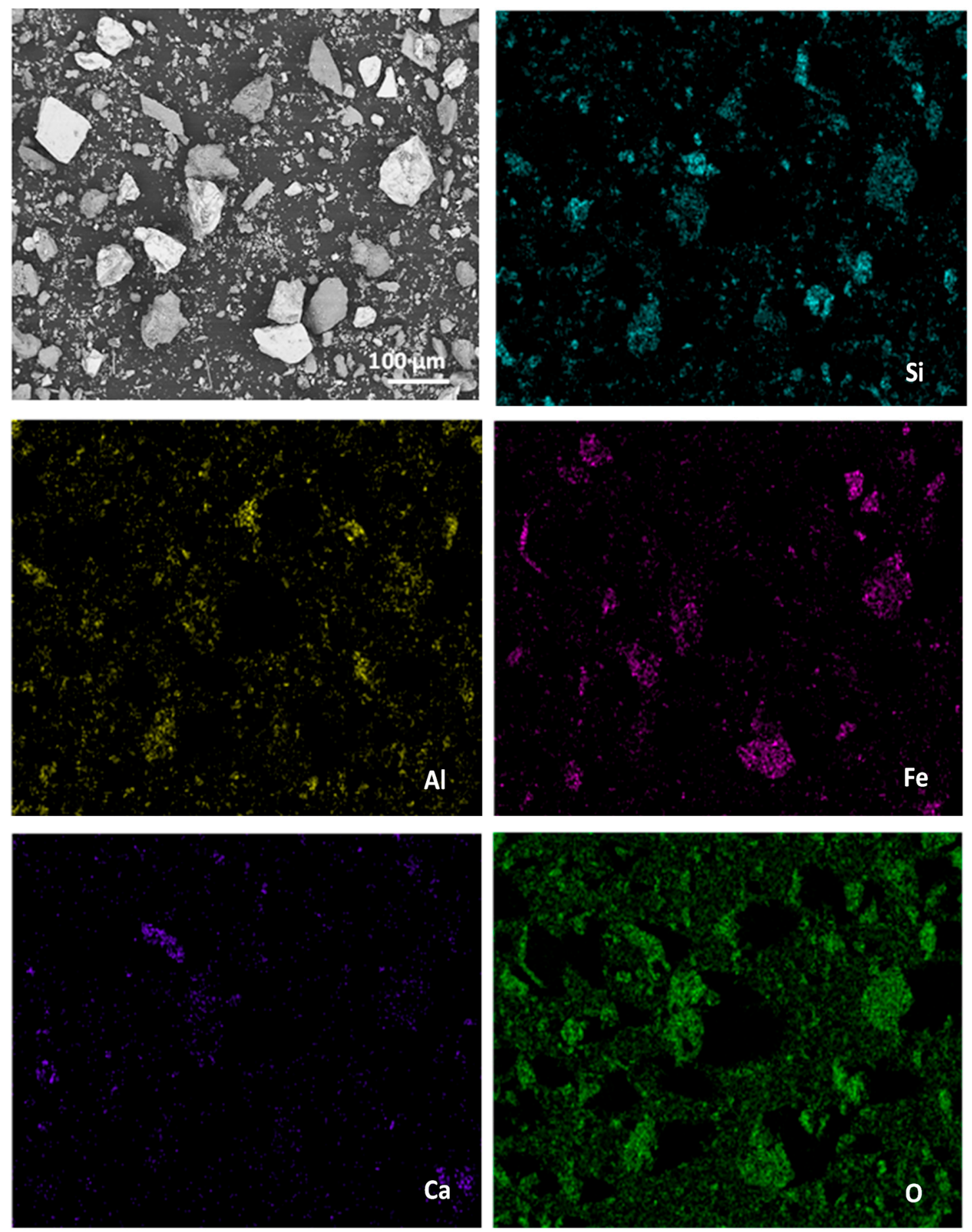

Figure 3. SEM images and EDX analysis of the industrial copper tailings particles. 


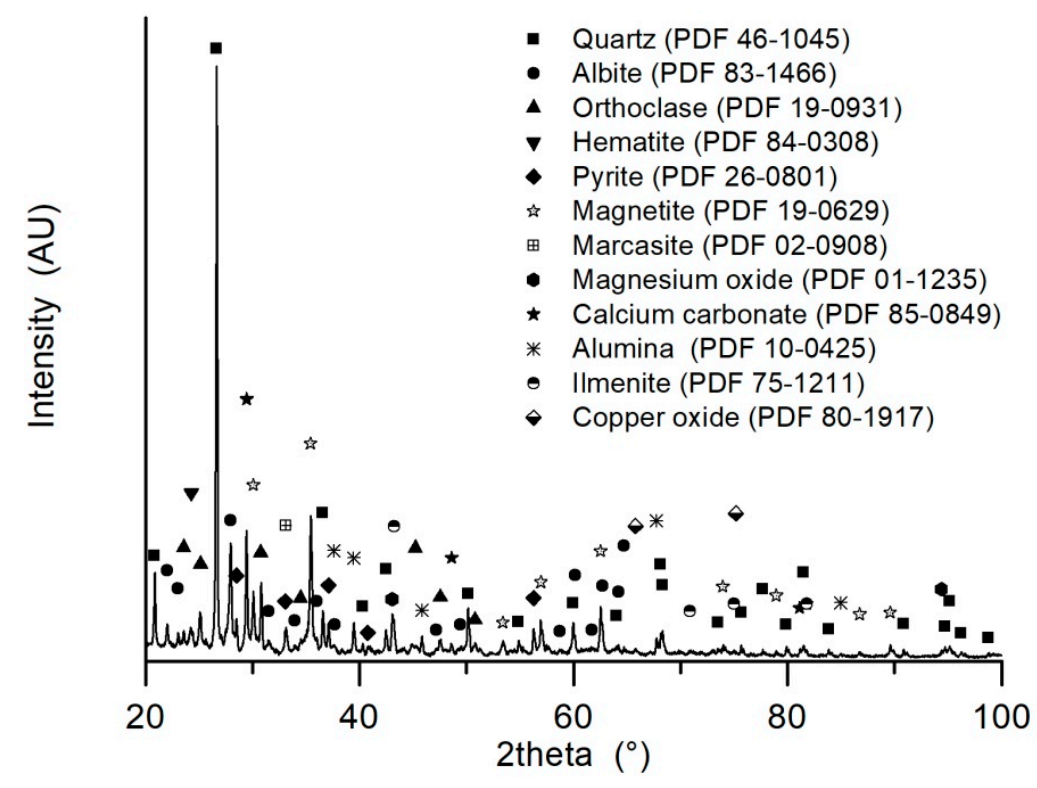

Figure 4. XRD patterns for industrial copper tailings particles.

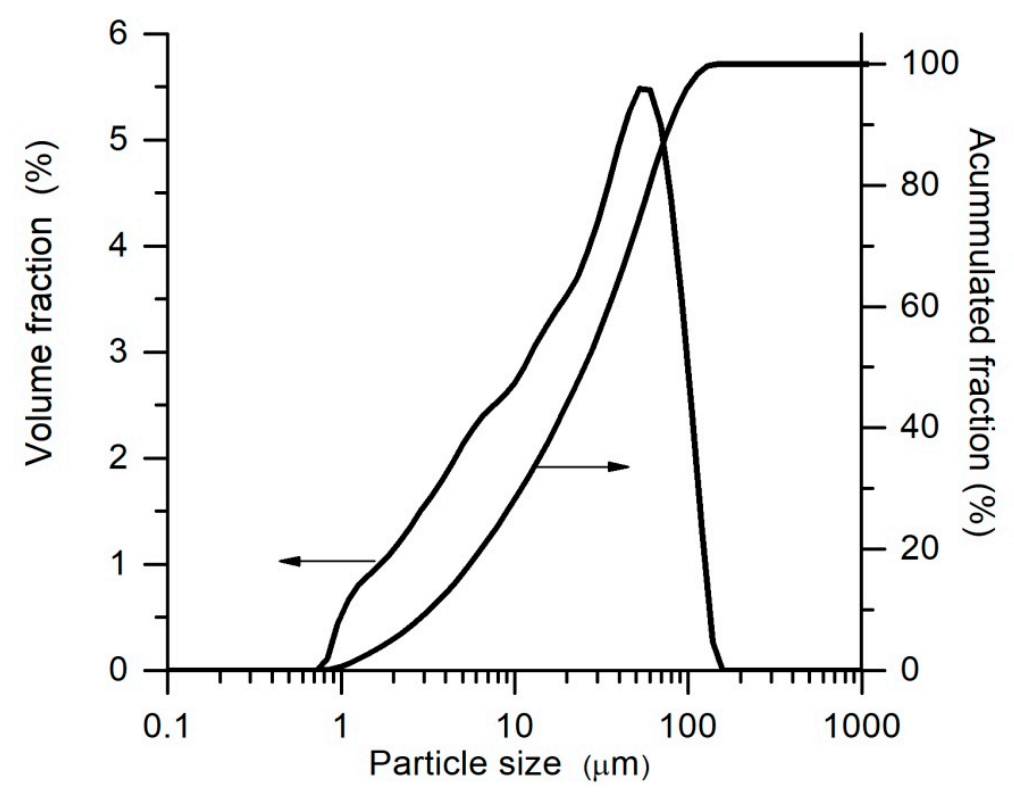

Figure 5. Particle size distribution of industrial copper tailings.

\subsection{Polarization Curves and Corrosion Rate}

Polarization curves for AISI 304L stainless steel at 6000, 7000, and $8000 \mathrm{rpm}$ are shown in Figure 6, for both $0.5 \mathrm{M} \mathrm{NaCl}$ and filtrate solutions as electrolytes. The characteristic polarization curve shape suggested that the kinetic mechanisms for the partial electrochemical anodic and cathodic reactions that had general validity were not significantly affected by the type of test solution. In the vicinity of the null current density where relevant corrosion parameters denoted as corrosion potential and corrosion current density evolved with time, the major governing partial reactions were oxygen reduction reaction (ORR) and iron oxidation reaction (IOR). In particular, the anodic branch showed two zones of interest: a passive region delimited by the corrosion potential and pitting potential approximately positioned at point $\mathrm{P}$ of Figure 6 , and an active region at more positive potentials. While the pitting potential was kept at a safe, more positive, value in comparison to the corrosion potential value, iron corrosion will proceed at a normal rate. Under certain circumstances, such as $\mathrm{pH}$ variations and the 
presence of aggressive ions in solution such as chlorides, a local corrosion potential on small areas can evolve to more positive values, close enough to pitting potential, generating a detrimental condition of autocatalytic pitting. In this form of corrosion, while passivity breakdown occurs on small areas of the metal surface, the rest remains passive $[9,14,16,30]$.
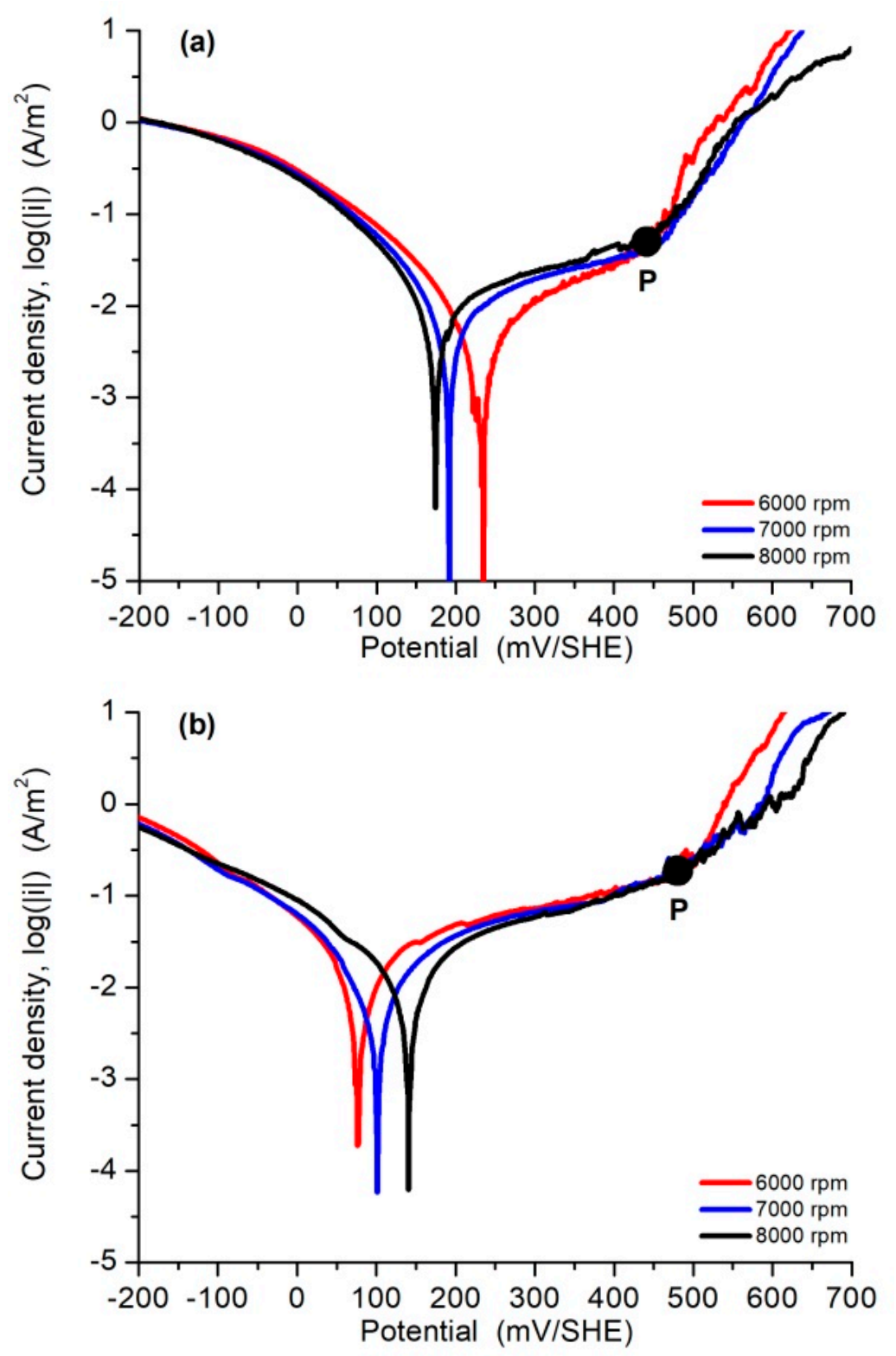

Figure 6. Tafel polarization curves for AISI 304L stainless steel electrodes immersed in the aerated $0.5 \mathrm{M} \mathrm{NaCl}(\mathbf{a})$, and filtrate solution form tailings slurries (b).

The deconstruction of polarization curves that was performed using the superposition model in the context of the mixed potential theory (Equations (2) and (3)) [29] is shown in Figure 7. For this purpose, the reaction mechanism for the ORR and IOR was simplified as a pure charge transfer mechanism. For the pitting anodic region, the modeling was performed considering the iron oxidation to Fe (II) as the main reaction after passive film breakdown by the presence of chloride ions [32,33]. Table 1 resumes the average of the corrosion and electrochemical parameters influenced by the rotating rate in $\mathrm{NaCl}$ and filtrate solutions obtained from the repetition of the complete set of experiments. 


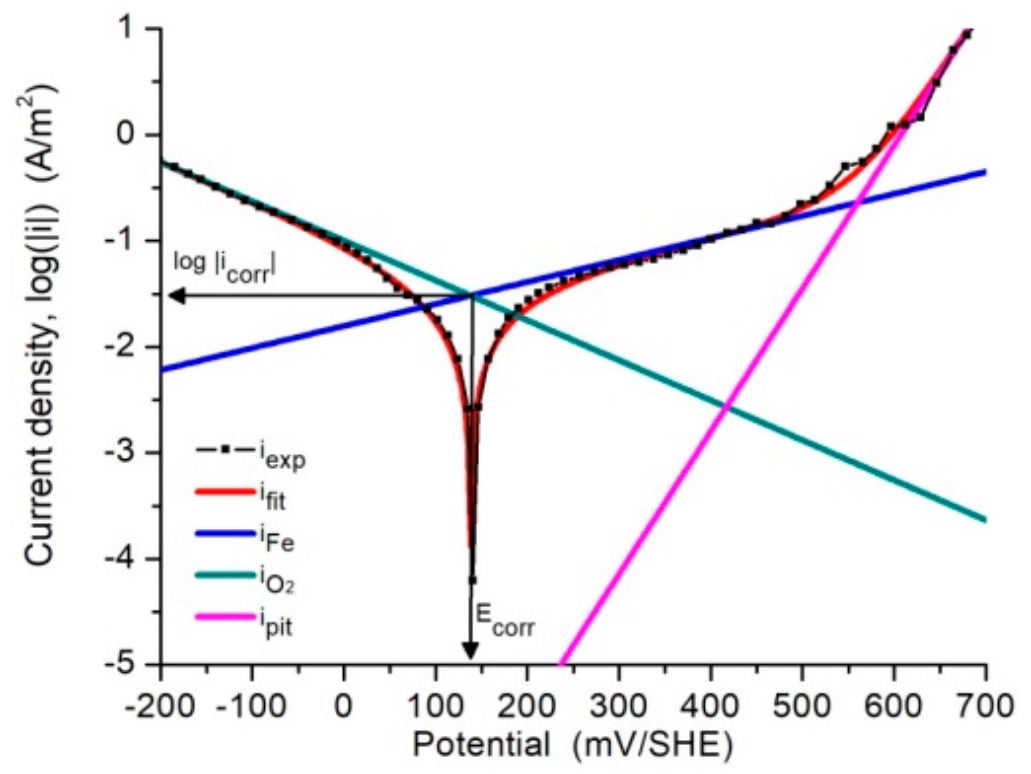

Figure 7. Synthesis of polarization curves for AISI 304L stainless steel immersed in filtered solution at $8000 \mathrm{rpm}$.

The excellent fitting results between the experimental and simulated values achieved by numerical minimization confirmed kinetic Equations (2) and (3). The differences observed between different polarization curves could be described as geometric distortions caused by the augmentation or reduction in various portions of the curve. These distortions were a consequence of differing values in some kinetic parameters. For example, the family of curves using the filtrate solution (Figure $6 \mathrm{~b}$ ) exhibited a shifting to higher current densities with the rotation rate on the cathodic region, while the contrary effect was observed in the anodic region. Particularly, an opposite effect was observed for the $\mathrm{NaCl}$ solution for both anodic and cathodic regions close to the current inversion potential. These effects were mainly a result of decreasing and increasing $i_{0, \mathrm{Fe}}$ values with the increasing rotation rate of filtrate, and $\mathrm{NaCl}$ solutions, respectively. In addition, pitting potential values (marked as $P$ points in Figure 6) with more positives with respect to $E_{\text {corr }}$ values were observed for filtrate in comparison to $\mathrm{NaCl}$ solutions. 
Table 1. Electrochemical and corrosion parameters for AISI 304L stainless steel in the $0.5 \mathrm{M} \mathrm{NaCl}$ and filtrate solution from tailings slurries.

\begin{tabular}{|c|c|c|c|c|c|c|c|c|c|c|c|}
\hline \multicolumn{12}{|c|}{$0.5 \mathrm{M} \mathrm{NaCl}$} \\
\hline Rotation Rate & \multicolumn{2}{|c|}{ Iron Oxidation } & \multicolumn{2}{|c|}{ Oxygen Reduction } & \multicolumn{2}{|c|}{ Pitting Corrosion } & \multicolumn{5}{|c|}{ Corrosion and Pitting Parameters } \\
\hline $\begin{array}{c}w, \\
\mathrm{rpm}\end{array}$ & $\begin{array}{l}i_{0, \mathrm{Fe}} \\
\mathrm{A} / \mathrm{m}^{2}\end{array}$ & $\begin{array}{c}b_{\mathrm{Fe}}, \\
\mathrm{mV} / \mathrm{dec}\end{array}$ & $\begin{array}{l}i_{0, \mathrm{O} 2} \\
\mathrm{~A} / \mathrm{m}^{2}\end{array}$ & $\begin{array}{c}b_{\mathrm{O} 2} \\
\mathrm{mV} / \mathrm{dec}\end{array}$ & $\begin{array}{l}i_{0, p i t}, \\
\mathrm{~A} / \mathrm{m}^{2}\end{array}$ & $\begin{array}{c}b_{\text {pit }} \\
\mathrm{mV} / \mathrm{dec}\end{array}$ & $\begin{array}{c}E_{\text {pit }} \\
\mathrm{mV} / \mathrm{SHE}\end{array}$ & $\begin{array}{c}E_{\text {corr }}, \\
\mathrm{mV} / \mathrm{SHE}\end{array}$ & $\begin{array}{l}E_{\text {pit }}-E_{\text {corr }} \\
\mathrm{mV} / \mathrm{SHE}\end{array}$ & $\begin{array}{l}i_{\text {corr }} \\
\mathrm{A} / \mathrm{m}^{2}\end{array}$ & $\begin{array}{c}C_{0} \\
\mathrm{mg} / \mathrm{cm}^{2} \cdot \mathrm{h}\end{array}$ \\
\hline 6000 & $5.1 \times 10^{-5}$ & 372 & $-8.6 \times 10^{-7}$ & -146 & $2.9 \times 10^{-20}$ & 59 & 437 & 227 & 210 & 0.010 & $1.07 \times 10^{-3}$ \\
\hline 7000 & $5.4 \times 10^{-4}$ & 566 & $-7.1 \times 10^{-7}$ & -146 & $9.7 \times 10^{-21}$ & 59 & 439 & 191 & 248 & 0.015 & $1.54 \times 10^{-3}$ \\
\hline 8000 & $1.4 \times 10^{-3}$ & 694 & $-6.8 \times 10^{-7}$ & -146 & $1.7 \times 10^{-20}$ & 59 & 427 & 173 & 254 & 0.020 & $2.05 \times 10^{-3}$ \\
\hline Average & $6.7 \times 10^{-4}$ & 544 & $-7.5 \times 10^{-7}$ & -146 & $1.9 \times 10^{-20}$ & 59 & 363 & 197 & 237 & 0.015 & $1.56 \times 10^{-3}$ \\
\hline \multicolumn{12}{|c|}{ Filtrate Solution } \\
\hline Rotation Rate & \multicolumn{2}{|c|}{ Iron Oxidation } & \multicolumn{2}{|c|}{ Oxygen Reduction } & \multicolumn{2}{|c|}{ Pitting Corrosion } & \multicolumn{5}{|c|}{ Corrosion and Pitting Parameters } \\
\hline $\begin{array}{l}w, \\
\text { rpm }\end{array}$ & $\begin{array}{r}i_{0, \mathrm{Fe}} \\
\mathrm{A} / \mathrm{m}^{2}\end{array}$ & $\begin{array}{c}b_{\mathrm{Fe}}, \\
\mathrm{mV} / \mathrm{dec}\end{array}$ & $\begin{array}{l}i_{0, \mathrm{O} 2} \\
\mathrm{~A} / \mathrm{m}^{2}\end{array}$ & $\begin{array}{c}b_{\mathrm{O} 2} \\
\mathrm{mV} / \mathrm{dec}\end{array}$ & $\begin{array}{l}i_{0, \mathrm{pit}} \\
\mathrm{A} / \mathrm{m}^{2}\end{array}$ & $\begin{array}{c}b_{\text {pit }} \\
\mathrm{mV} / \mathrm{dec}\end{array}$ & $\begin{array}{c}E_{\text {pit }} \\
\mathrm{mV} / \mathrm{SHE}\end{array}$ & $\begin{array}{c}E_{\text {corr }} \\
\mathrm{mV} / \mathrm{SHE}\end{array}$ & $\begin{array}{l}E_{\text {pit }}-E_{\text {corr }} \\
\mathrm{mV} / \mathrm{SHE}\end{array}$ & $\begin{array}{l}i_{\text {corr }} \\
\mathrm{A} / \mathrm{m}^{2}\end{array}$ & $\begin{array}{c}\mathrm{C}_{0} \\
\mathrm{mg} / \mathrm{cm}^{2} \cdot \mathrm{h}\end{array}$ \\
\hline 6000 & $2.9 \times 10^{-3}$ & 614 & $-4.7 \times 10^{-5}$ & -224 & $6.6 \times 10^{-19}$ & 64 & 479 & 75 & 404 & 0.040 & $4.19 \times 10^{-3}$ \\
\hline 7000 & $1.2 \times 10^{-3}$ & 489 & $-7.6 \times 10^{-5}$ & -238 & $1.9 \times 10^{-18}$ & 68 & 497 & 100 & 397 & 0.035 & $3.60 \times 10^{-3}$ \\
\hline 8000 & $8.3 \times 10^{-4}$ & 482 & $-1.7 \times 10^{-4}$ & -265 & $3.4 \times 10^{-17}$ & 74 & 500 & 141 & 359 & 0.030 & $3.16 \times 10^{-3}$ \\
\hline Average & $1.6 \times 10^{-3}$ & 528 & $-9.7 \times 10^{-5}$ & -242 & $1.2 \times 10^{-17}$ & 69 & 492 & 105 & 387 & 0.035 & $4.65 \times 10^{-3}$ \\
\hline
\end{tabular}


Another interesting observation for filtrate solutions is the $E_{\text {corr }}$ shifting towards more positive values with increasing rotation rate, while for $\mathrm{NaCl}$ solutions $E_{\text {corr }}$ shifted in the opposite direction under the same condition. These patterns can be originated and discussed in terms of the $\mathrm{pH}$ solution, and inorganic and organic compounds that prevail in filtrate solutions after being dosed in the froth flotation process. In short, high rotation rates caused an increase in the chemical species concentration on the metallic surface which was combined with a variable hydroxyl concentration. These factors could affect the onset of the anodic process extending the potential range of the active-passive region and promoting changes in the stability of the passive film. For the anodic region, the apparent shorter passivity plateau was indicative of combined events attributed to an active IOR and to the formation of a spontaneous passive film on the stainless steel surface [33]. Other authors report that this passive film is mainly composed of an internal layer of chromium oxides and an external layer of iron oxides, and that its rupture is more likely to occur at susceptible sites in the passive film, such as inclusions, second particles phases, defects, and grain boundaries segregated by solutes [1,33-36]. On the other hand, it is interesting to note that the $E_{\text {corr }}$ value was in part an expression of higher $i_{0, \mathrm{Fe}}$ values observed in the filtrate in comparison to $\mathrm{NaCl}$ solutions. Concerning the variational patterns of $\left|b_{\mathrm{O} 2}\right|$ values, while higher values were observed for the filtrate solution $(\equiv 242 \mathrm{mV} / \mathrm{dec})$ in comparison with the $\mathrm{NaCl}$ solution $\left(\equiv 146 \mathrm{mV} / \mathrm{dec}\right.$ ), there was no significant changes with the rotation rates. These $\left|b_{\mathrm{O} 2}\right|$ values for the $\mathrm{NaCl}$ solution were similar to those reported in literature for stainless steel samples, which ranged between $140 \mathrm{mV} / \mathrm{dec}$ [37-39]. The ORR kinetics showed an uneven $i_{0, \mathrm{O} 2}$ change with rotation rate (Table 1 ) characterized by lower and higher $i_{0, \mathrm{O} 2}$ values at higher rotation rates for the $\mathrm{NaCl}$ and filtrate solution, respectively. Relative changes in the cathodic kinetic parameters can be explained in terms of surface coverage due to oxides or adsorbed chemical species. For the ORR on stainless steel specimens, a low surface coverage can be associated with lower $\left|b_{\mathrm{O} 2}\right|$ values, which favor a thicker layer of oxides and/or adsorbed species [39,40]. Under these considerations, our results for $\mathrm{NaCl}$ suggested a thinner oxide layer in comparison to that in the filtrate solution. These results are in agreement with the higher $i_{0, \mathrm{O} 2}$ values for the filtrate solution as a result of a more alkaline $\mathrm{pH}$. For the pitting anodic region, it was seen that the test solution did not have a significant effect, as indicated by the small variations in the $b_{\text {pit }}$ and $i_{0, \text { pit }}$ values. The low $b_{\text {pit }}$ values (between 59 and $69 \mathrm{mV} / \mathrm{dec}$ ) in comparison with the $b_{\mathrm{Fe}}$ values (between 544 and $528 \mathrm{mV} / \mathrm{dec}$ ) in the active region clearly indicated a significant tendency toward oxidation, meaning an accelerated breakdown of the passive film deposited on the metallic surface.

\subsection{Wear Behavior and Synergism}

To visualize the influence of the rotation rate on the wear of AISI 304L stainless steel, the weight loss values due to pure corrosion, pure erosion, and erosion-corrosion are summarized in Figure 8 . These results showed that for pure corrosion, the weight loss in $\mathrm{NaCl}$ increased with the rotation rate, in contrast with the results obtained for the filtrate solution where the weight loss was decreasing. The influence of the solution test showed higher weight loss values in the filtrate solution than that obtained for the $\mathrm{NaCl}$ solution. As was discussed in the previous section, its results can be attributed to a mixed effect due to the presence of inorganic and organic species coming from the froth flotation process that promotes changes in the solution $\mathrm{pH}$ and variation on the ORR and IOR kinetics parameters. Additionally, the results for pure erosion showed that the weight loss increased from 0.0139 to $0.0196 \mathrm{mg} / \mathrm{h} \cdot \mathrm{cm}^{2}$ at 6000 and $7000 \mathrm{rpm}$, respectively, up to values of $0.0429 \mathrm{mg} / \mathrm{h} \cdot \mathrm{cm}^{2}$ at $8000 \mathrm{rpm}$. These values were higher than those obtained by a pure corrosion mechanism revealing an important influence of the erosion process on stainless steel wear. The identification of the regime boundaries between erosion and corrosion can be determined by the argument given by Stack, James, and $\mathrm{Lu}$ [41] who expressed this regime in terms of the ratio $C_{0} / W_{0}$. In this work, the ratio values were $0.077,0.079$, and 0.048 for the $\mathrm{NaCl}$ solution and $0.300,0.184$, and 0.074 for the filtrate solution at 6000,7000 , and $8000 \mathrm{rpm}$, respectively. These ratio values were lower than 0.1 for $\mathrm{NaCl}$ solutions at all rotation rates indicating an erosion-dominated regime, and values that varied between 0.1 and 1 
for the filtrated solution indicating an erosion-corrosion regime at 6000 and $7000 \mathrm{rpm}$ changed to an erosion-dominated regime at $8000 \mathrm{rpm}$. Concerning the erosion-corrosion tests, which were performed under an OCP condition in tailing slurries, the results revealed that the presence of industrial tailing particles promoted an increase in $T_{w l}$ with the rotation rate. It is interesting to note that when AISI $304 \mathrm{~L}$ stainless steel was exposed to the erosion-corrosion process under an OCP condition, the wear was higher and lower than $C_{0}$ and $W_{0}$ values, respectively. In order to evaluate the combined effect of the erosion and corrosion rate, the synergism term was determined from Equation (1), and is shown in Figure 9. As is shown in the figure, negative values were exhibited for this term, which indicated that the AISI 304L had an antagonistic effect when exposed to an industrial tailing slurry [42]. Additionally, from the results, it was clearly seen that the corrosion mechanism contributed positively to the stainless steel wear. However, when the samples were subjected to a pure erosion mechanism, the wear was much higher than that observed by the erosion-corrosion mechanism. In concordance with the results obtained in Table 1, an explanation of this behavior can be conducted in terms of the passive film resistance against the abrasive action exerted by impinging tailing particles. To understand this, it is important to discuss passive film stability during the erosion experiments. According to the polarization curves (Figure 6) and Pourbaix diagram for chromium [43], it is expected that at $-300 \mathrm{mV} / \mathrm{SHE}$ the cathodic ORR occurs in the presence of an ultrathin passive layer of iron and chromium oxides spontaneously formed on the AISI 304L steel. However, under this cathodic potential and $\mathrm{pH}$ slurry of 8.05 , the stability of this ultrathin passive film can be partially dissolved as a result of $\mathrm{Cr}$ (III) reduction to a more soluble $\mathrm{Cr}$ (II) oxide [32], which is also more sensitive to the presence of chloride ions [43]. This explains the observed behavior by which the antagonistic effect is enhanced at higher rotation rates $(8000 \mathrm{rpm})$, which is originated from large erosion rates associated with abrasive action exerted by tailing particles on a bare surface specimen.

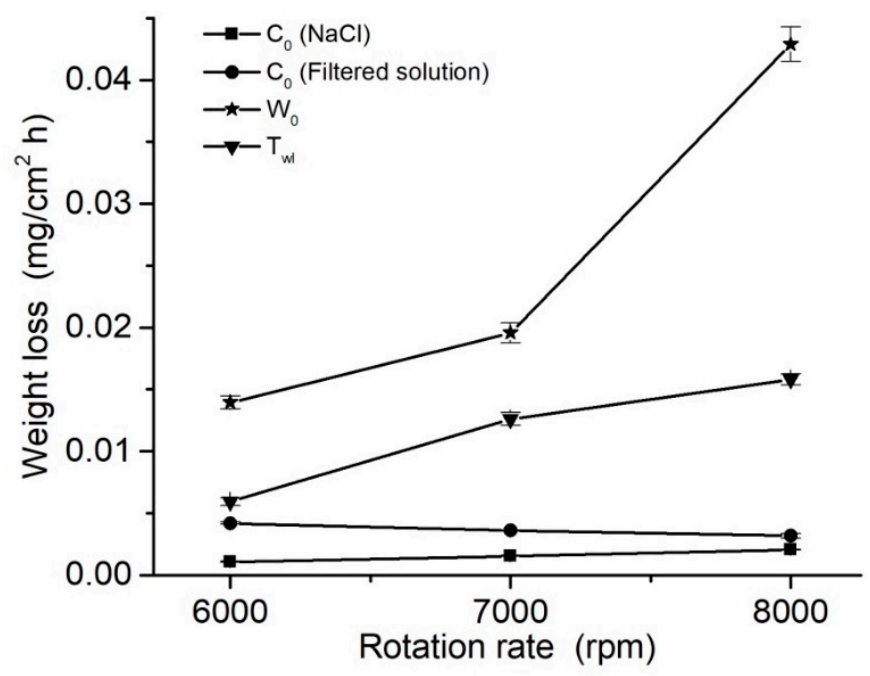

Figure 8. Individual weight loss rates for AISI 304L stainless steel in the absence and presence of erodent tailing particles at different rotation rates. The scatters in the weight loss results were less than $\pm 6.5 \%$ of the average value. 


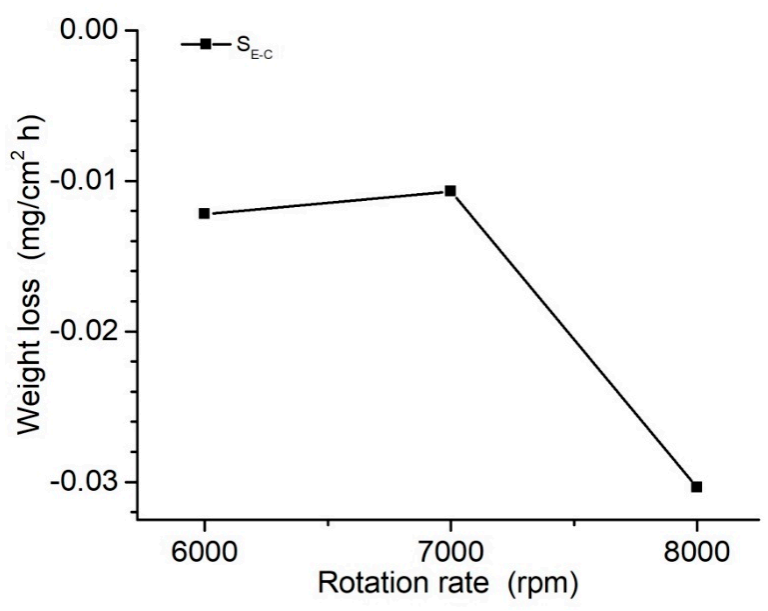

Figure 9. Synergy effect $\left(S_{\mathrm{E}-\mathrm{C}}\right)$ for AISI 304L stainless steel determined by using Equation (1).

\subsection{Morphological Observations}

Optical images of AISI 304L stainless steel after exposure to a combination of erosion-corrosion tests at $6000 \mathrm{rpm}$ are shown in Figure 10. The reference surface (Figure 10a) did not show any defects caused by corrosion and erosion, other than well-defined radial marks of approximately $2 \mu \mathrm{m}$ in width which was attributed to the initial abrading process. All specimens subjected to an erosion-corrosion (Figure 10b) and erosion processes (Figure 10c) did not show significant differences in the gross morphological patterns between them. These patterns for both degradation mechanisms were characterized by well-defined lines due to the impact of the erodent particles on the metallic surface, which were more prominent for the erosion-corrosion process that also showed pitting cavities due to chloride influence. Additionally, SEM images in Figure 11, confirmed the presence of an oxide layer on the surface, which was less intense in specimens subjected to an erosion-corrosion process (Figure 11a), with the presence of pitting sites. It is important to note that the surface morphology of the pure erosion test appeared as a rougher oxide layer (Figure 11b). At first sight, these results were in concordance with weight loss data that indicated higher values for the pure erosion case. However, as previously mentioned, in the pure erosion test, the passive layer spontaneously formed on the stainless steel originated from $\mathrm{Cr}$ (II) formation, solubilization, and removal steps generating conditions for uniform corrosion.
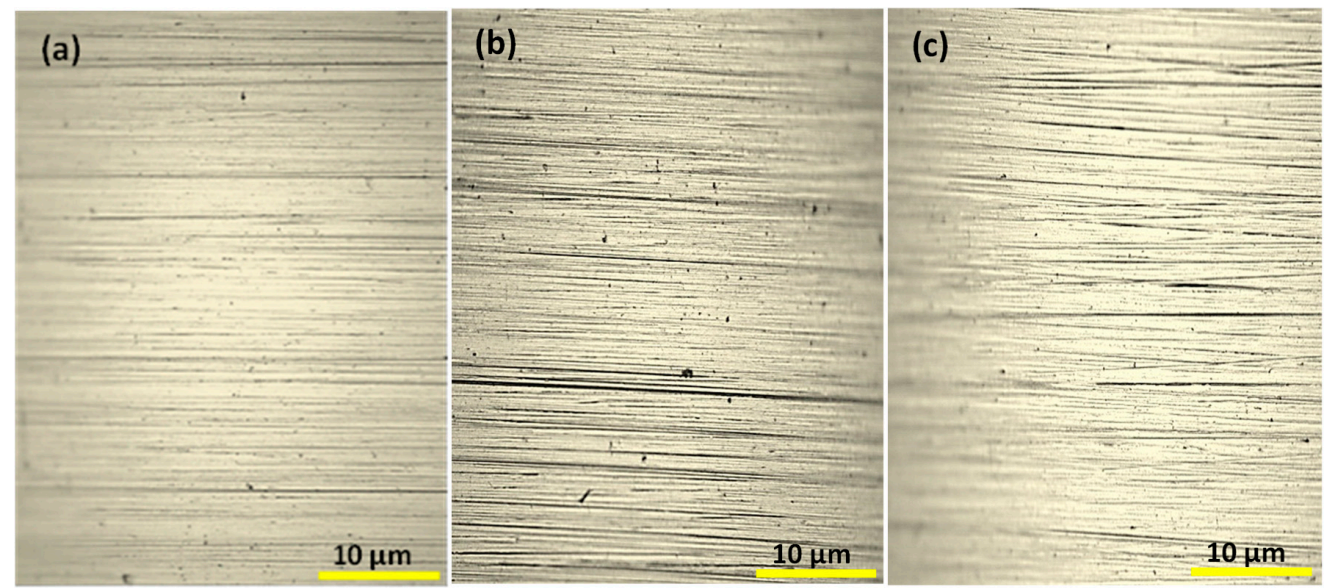

Figure 10. Optical micrographs of AISI 304L stainless steel. Initial condition (a), after test of erosion-corrosion (b), and after test for pure erosion (c), in tailings slurries at $6000 \mathrm{rpm}$. 

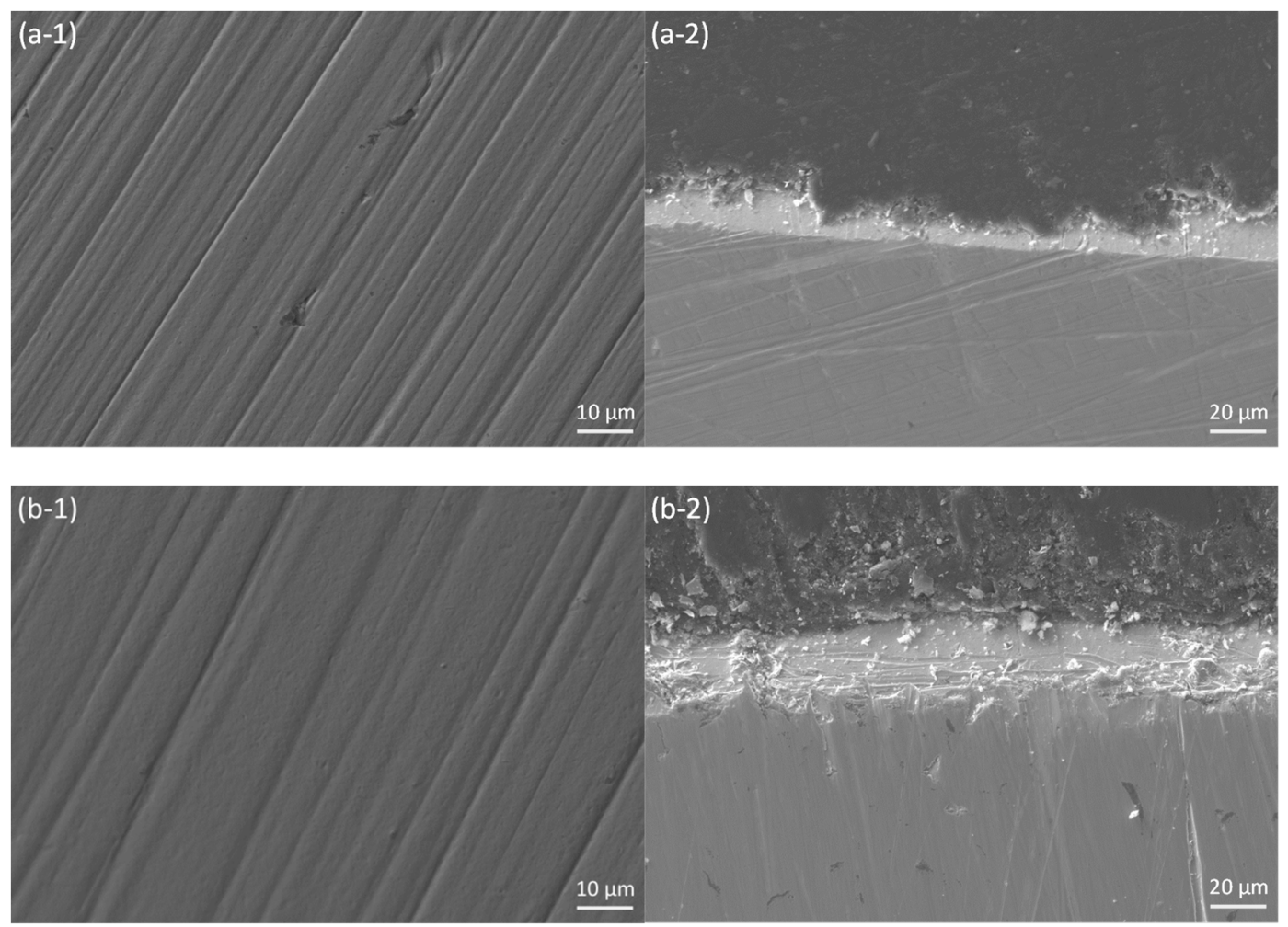

Figure 11. SEM morphologies for AISI 304L stainless steel after $44 \mathrm{~h}$ of erosion-corrosion (a) and erosion (b), process in a tailing slurry at $6000 \mathrm{rpm}$. Top section (1) and cross section (2).

\section{Conclusions}

In this work, we studied the wear of stainless steel AISI 304L under three different mechanisms of pure corrosion, pure erosion, and erosion-corrosion using industrial tailings from the copper mining industry as erodent media. Due to the presence of industrial additives that could impart significant interactions between erodent particles and fluid, referential corrosion tests in a $0.5 \mathrm{M} \mathrm{NaCl}$ solution as well as in the filtrate solution from the slurry were performed. The results show that the presence of chemical additives used in the froth flotation process generates an interaction with the tailing particles, increasing the corrosion rate of AISI 304L stainless steel in comparison with a $\mathrm{NaCl}$ solution. These results can be explained in terms of variations in the passive film stability promoted by chemical changes in the test solution. The pure erosion tests that have higher erosion rate values when increasing the rotation rate as compared to pure corrosion may be due to a mixed effect of iron and chromium oxide chemical dissolution and mechanical wear of stainless steel caused by the impact of tailing particles. In this respect, for the experimental conditions of this work, an erosion-dominated regime was found in $\mathrm{NaCl}$ solutions, instead of a mixed erosion-corrosion regime for the filtrate solution. Under erosion-corrosion test conditions, the wear by erosion-corrosion was lower and higher than the values obtained for pure erosion and pure corrosion, respectively. Based on these results, an antagonistic behavior was found for AISI 304L exposed to an industrial tailings slurry, which can be attributed to the stability of the passive film under an OCP condition that promotes less wear damage in comparison to a pure erosion mechanism. The morphological examination confirms this antagonistic behavior through a more homogeneous oxide film deposited under the erosion-corrosion process.

Author Contributions: Conceptualization, methodology, data analysis, and writing —original daft preparation, Á.S.; visualization, writing-review and editing, L.C.; resources and editing, F.P.; resources and visualization, F.G. All authors have read and agreed to the published version of the manuscript.

Funding: This research was funded by the University of Atacama and the DIUDA project (DIUDA-22315). 
Acknowledgments: The authors would like to thank the Department of Metallurgy Department of University of Atacama for the chemical analysis.

Conflicts of Interest: The authors declare no conflict of interest.

\section{References}

1. Hakiki, N.E.; Montemor, M.F.; Ferreira, M.G.S.; da Cunha Belo, M. Semiconducting properties of thermally grown oxide films on AISI 304 stainless steel. Corros. Sci. 2000, 42, 687-702. [CrossRef]

2. Abreu, C.M.; Cristóbal, M.J.; Losada, R.; Nóvoa, X.R.; Pena, G.; Pérez, M.C. Long-term behaviour of AISI 304L passive layer in chloride containing medium. Electrochim. Acta 2006, 51, 1881-1890. [CrossRef]

3. Ai, Z.; Sun, W.; Jiang, J.; Song, D.; Ma, H.; Zhang, J.; Wang, D. Passivation characteristics of alloy corrosion-resistant steel $\mathrm{Cr} 10 \mathrm{Mo} 1$ in simulating concrete pore solutions: Combination effects of $\mathrm{pH}$ and chloride. Materials 2016, 9, 749. [CrossRef] [PubMed]

4. Fernandez-Domene, R.M.; Sánchez-Tovar, R.S.; García-Antón, J. Passive behavior and passivity breakdown of AISI 304 in LiBr solutions through scanning electrochemical microscopy. J. Electrochem. Soc. 2014, 161, C565-C572. [CrossRef]

5. Wharton, J.A.; Wood, R.J.K. Influence of flow conditions on the corrosion of AISI 304L stainless steel. Wear 2004, 256, 525-536. [CrossRef]

6. Klapper, H.S.; Goellner, J.; Burkert, A.; Heyn, A. Environmental factors affecting pitting corrosion of type 304 stainless steel investigated by electrochemical noise measurements under potentiostatic control. Corr. Sci. 2013, 75, 239-247. [CrossRef]

7. Refaey, S.A.M.; Taha, F.; Abd El-Malak, A.M. Corrosion and inhibition of stainless steel pitting corrosion in alkaline medium and the effect of $\mathrm{Cl}^{-}$and $\mathrm{Br}^{-}$anions. Appl. Surf. Sci. 2005, 242, 114-120. [CrossRef]

8. Martins, C.M.B.; Moreira, J.L.; Martins, J.I. Corrosion in water supply pipe stainless steel 304 and a supply line of helium in stainless steel 316. Eng. Fail. Anal. 2014, 39, 65-71. [CrossRef]

9. Aghuy, A.A.; Zakeri, M.; Moayed, M.H.; Mazinani, M. Effect of grain size on pitting corrosion of 304L austenitic stainless steel. Corros. Sci. 2015, 94, 368-376. [CrossRef]

10. Chong, P.H.; Liu, Z.; Wang, X.Y.; Skeldon, P. Pitting corrosion behaviour of large area laser surface treated 304L stainless-steel. Thin Solid Films 2004, 453-454, 388-393. [CrossRef]

11. Biehler, J.; Hoche, H.; Oechsner, M. Corrosion properties of polished and shot-peened austenitic stainless steel 304L and 316L with and without plasma nitriding. Surf. Coat. Technol. 2017, 313, 40-46. [CrossRef]

12. Lu, B.T.; Mao, L.C.; Luo, J.L. Hydrodynamic effects on erosion-enhanced corrosion of stainless steel in aqueous slurries. Electrochim. Acta 2010, 56, 85-92. [CrossRef]

13. Wood, R.J.K.; Walker, J.C.; Harvey, T.J.; Wang, S.; Rajahram, S.S. Influence of microstructure on the erosion and erosion-corrosion characteristics of 316 stainless steel. Wear 2013, 306, 254-262. [CrossRef]

14. Xu, Y.; Liu, L.; Zhou, Q.; Wang, X.; Tan, M.Y.; Huang, Y. An overview of major experimental methods and apparatus for measuring and investigating erosion-corrosion of ferrous-based steels. Metals 2020, 10, 180. [CrossRef]

15. Zhang, Y.; Yin, X.; Yan, F. Effect of halide concentration on tribocorrosion behavior of 304 SS in artificial seawater. Corros. Sci. 2015, 99, 272-280. [CrossRef]

16. Khan, R.; Ya, H.H.; Pao, W. An experimental study on the erosion-corrosion performance of AISI 1018 carbon steel and AISI 304L stainless steel 90-degree elbow pipe. Metals 2019, 9, 1260. [CrossRef]

17. Zheng, Z.B.; Zheng, Y.G. Erosion-enhanced corrosion of stainless steel and carbon steel measured electrochemically under liquid and slurry impingement. Corros. Sci. 2016, 102, 259-268. [CrossRef]

18. Bermúdez, M.D.; Carrión, F.J.; Martínez-Nicolás, G.; López, R. Erosion-corrosion of stainless steels, titanium, tantalum and zirconium. Wear 2005, 258, 693-700. [CrossRef]

19. Saada, F.B.; Antar, Z.; Elleuch, K.; Ponthiaux, P. On the tribocorrosion behavior of 304L stainless steel in olive pomace/tap water filtrate. Wear 2015, 328-329, 509-517. [CrossRef]

20. Stack, M.M.; Jana, B.D.; Abdelrahman, S.M. Models and Mechanisms of Erosion-Corrosion in Metals. In Tribocorrosion of Passive Metals and Coatings, 1st ed.; Landolt, D., Mischler, S., Eds.; Woodhead Publishing Limited: Cambridge, UK, 2011; Volume 1, pp. 153-186.

21. Yang, Y.; Cheng, Y.F. Parametric effects on the erosion-corrosion rate and mechanism of carbon steel pipes in oil sands slurry. Wear 2012, 276-277, 141-148. [CrossRef] 
22. Li, P.; Zhao, Y.; Wang, L. Research on erosion-corrosion rate of 304 stainless steel in acidic slurry via experimental design method. Materials 2019, 12, 2330. [CrossRef] [PubMed]

23. Yi, J.Z.; Hu, H.X.; Wang, Z.B.; Zheng, Y.G. Comparison of critical flow velocity for erosion-corrosion of six stainless steels in $3.5 \mathrm{wt} \% \mathrm{NaCl}$ solution containing $2 \mathrm{wt} \%$ silica sand particles. Wear 2018, 416-417, 62-71. [CrossRef]

24. Javaheri, V.; Porter, D.; Kuokkala, V.T. Slurry erosion of steel-Review of tests, mechanisms and materials. Wear 2018, 408-409, 248-273. [CrossRef]

25. Karafyllias, G.; Galloway, A.; Humphries, E. The effect of low $\mathrm{pH}$ in erosion-corrosion resistance of high chromium cast irons and stainless steels. Wear 2019, 420-421, 79-86. [CrossRef]

26. Aguirre, J.; Walczak, M. Effect of dissolved copper ions on erosion-corrosion synergy of X65 steel in simulated copper tailing slurry. Tribol. Int. 2017, 114, 329-336. [CrossRef]

27. Lindgren, M.; Perolainen, J. Slurry pot investigation of the influence of erodent characteristics on the erosion resistance of austenitic and duplex stainless steel grades. Wear 2014, 319, 38-48. [CrossRef]

28. ASTM International. ASTM G119-04: Standard Guide for Determining Synergism Between Wear and Corrosion; ASTM International: West Conshohocken, PA, USA, 2004.

29. Soliz, A.; Cáceres, L. Corrosion of a carbon steel cylindrical band exposed to a concentrated $\mathrm{NaCl}$ solution flowing through an annular flow cell. J. Electrochem. Soc. 2015, 162, C385-C395. [CrossRef]

30. McCafferty, E. Introduction to Corrosion Science, 1st ed.; Springer: New York, NY, USA, 2010; pp. $13-31$.

31. ASTM International. ASTM E407-07E1: Standard Practice for Microetching Metals and Alloys; ASTM International: West Conshohocken, PA, USA, 2012.

32. Klemm, J.; Klemm, S.O.; Duarte, M.J.; Rossrucker, L.; Mayrhofer, K.J.J.; Renner, F.U. Multi-element-resolved electrochemical corrosion analysis. Part, I. Dissolution behavior and passivity of amorphous $\mathrm{Fe}_{50} \mathrm{Cr}_{15} \mathrm{Mo}_{14} \mathrm{C}_{15} \mathrm{~B}_{6}$. Corros. Sci. 2014, 89, 59-68. [CrossRef]

33. Ogle, K.; Mokaddem, M.; Volovitch, P. Atomic emission spectroelectrochemistry applied to dealloying phenomena II. Selective dissolution of iron and chromium during active-passive cycles of an austenitic stainless steel. Electrochim. Acta 2010, 55, 913-921. [CrossRef]

34. Olsson, C.O.A.; Landolt, D. Passive films on stainless steels-chemistry, structure and growth. Electrochim. Acta 2003, 48, 1093-1104. [CrossRef]

35. Montemor, M.F.; Ferreira, M.G.S.; Hakiki, N.E.; Da Cunha Belo, M. Chemical composition and electronic structure of the oxide films formed on 316L stainless steel and nickel based alloys in high temperature aqueous environments. Corros. Sci. 2000, 42, 1635-1650. [CrossRef]

36. Soliz, A.; Mayrhofer, K.J.J.; Cáceres, L. Influence of hydrodynamic flow patterns on the corrosion behavior of carbon steel in a neutral LiBr solution. Int. J. Electrochem. Sci. 2018, 13, 10050-10075. [CrossRef]

37. Alexander, C.L.; Kelly, R.G.; Liu, C.; Carpenter, J.; Alshanoon, A.; Bryan, C.; Katona, R.M.; Schindelholz, E. Oxygen reduction on stainless steel in concentrated chloride media. J. Electrochem. Soc. 2018, 165, C869-C877. [CrossRef]

38. Gojković, S.L.J.; Zečević, S.K.; Obradović, M.D.; Dražić, D.M. Oxygen reduction on a duplex stainless steel. Corros. Sci. 1998, 40, 849-860. [CrossRef]

39. Babić, R.; Metikoš-Huković, M. Oxygen reduction on stainless steel. J. Appl. Electrochem. 1993, 23, $352-357$. [CrossRef]

40. Rybalka, K.V.; Beketaeva, L.A.; Davydov, A.D. Effect of self-passivation on the electrochemical and corrosion behaviour of alloy C-22 in $\mathrm{NaCl}$ solutions. Corros. Sci. 2012, 54, 161-166. [CrossRef]

41. Stack, M.M.; James, J.S.; Lu, Q. Erosion-corrosion of chromium steel in a rotating cylinder electrode system: Some comments on particle size effects. Wear 2004, 256, 557-564. [CrossRef]

42. Stack, M.M.; Pungwiwat, N. Erosion-corrosion mapping of Fe in aqueous slurries: Some views on a new rationale for defining the erosion-corrosion interaction. Wear 2004, 256, 565-576. [CrossRef]

43. Pourbaix, M. Atlas of Electrocemical Equilibria in Aqueous Solutions, 2nd ed.; National Association of Corrosion Engineers: Houston, TX, USA, 1974; pp. 256-271.

(C) 2020 by the authors. Licensee MDPI, Basel, Switzerland. This article is an open access article distributed under the terms and conditions of the Creative Commons Attribution (CC BY) license (http://creativecommons.org/licenses/by/4.0/). 